\title{
Working Time in Public, Private, and Nonprofit Organizations: What Influences Prospects for Employee Control?
}

\section{Abigail Powell and Natasha Cortis}

\begin{abstract}
Employee control over work-time arrangements promotes work-family reconciliation and buffers against stress. But which human service context provides employees with the best opportunities to control their work schedules? Analysis of Australian survey data shows that after accounting for the low levels of work-time control in human service occupations like teaching and nursing, nonprofit organizations offer superior prospects for work-time control. However, whether this is true is strongly influenced by other occupational, employment and personal characteristics, such that for personal-care workers, work-time control is lowest in nonprofit organizations.
\end{abstract}

KEYWORDS: Flexible work arrangements, gender, human resource management, human service organizations, nonprofit sector, women, work-time

\section{Introduction}

Although women's workforce participation has increased in recent decades, entrenched gender norms mean that on average, women's working conditions are still inferior to men's, with inequality evident across public, private, and nonprofit human service organizations and in the wider workforce. While the gender division of domestic labor and male breadwinner employment models narrow opportunities for both men and women, gendered norms and practices more often undermine women's status in the workplace, as women maintain more responsibility for unpaid domestic work and child care than men (Sang \& Powell, 2012). Like in other countries, this is borne out in Australia, where women's rates of part-time work, and time spent on child care and domestic work are particularly high and where highly sex-segregated labor markets mean high proportions of women work in the feminized industries of health, education, and social welfare provision, often for public and nonprofit employers (Barns \& Preston, 2010; Baxter, 2002; Craig \& Bittman, 2008; OECD, 2007).

In the human services as in other industries, flexible work arrangements, such as part-time and variable hours can help employees to reduce conflict between home and work and to deal with the time pressures of each domain (ten Brummelhuis \& Van Der Lippe, 2010). Where time pressures are poorly managed, combining work and family will be problematic, raising health risks and threatening organizational performance, with costs for government, employers, and service users as well as employees (Allen, Herst, Bruck, \& Sutton, 2000; OECD, 2007; Pocock, Skinner, \& Williams, 2012; Sang \& Powell, 2012). Conversely, flexible work arrangements can have positive effects on individual and family outcomes, minimizing work-family conflict and work-related stress and promoting employees' capacity to fulfill family responsibilities (Carlson, Grzywacz, \& Kacmar, 2010; Kinnunen \& Mauno, 1998).

Research has shown however that access to flexible arrangements and the impacts of these arrangements tend to vary, depending on institutional and regulatory context and constraints, and 
on the balance of power between employees and employers in shaping their work-time arrangements (Berg, Appelbaum, Bailey, \& Kalleberg, 2004; Donnelly, Proctor-Thomson, \& Plimmer, 2012; McCrate, 2012; Sweet, Pitt-Catsouphes, Besen, \& Golden, 2014). Some practices, such as variability in work times, have been criticized for providing employers with primary control over flexible work arrangements, while contributing to unpredictable, irregular hours and income for workers seeking flexible hours (McCrate, 2012). The irregular work schedules associated with casual or zero-hours contracts, for example, may offer more advantage to employers than employees, as they lower costs by adjusting staffing to reflect short-term fluctuations in demand (Beers, 2000; Berg, Bosch, \& Charest, 2014; Chung \& Tijdens, 2013; Daly, 2014; Stein, 2015). On this basis, the most common measures of flexibility - whether or not flexible work arrangements are available or whether or not employees work irregular hours-risk misrepresenting the extent to which arrangements benefit employees, as they do not capture the extent to which employees and employers influence whether and how nonstandard arrangements are used (Sweet et al., 2014).

We examine work-time flexibility using a different approach. Rather than assessing the availability or take-up of particular arrangements, we are concerned with the level of control employees feel they have over their working time.1 Work-time control refers to employees' decision making over start and end times, when to take a break, when to take leave, how work-time is distributed across the week, and whether and when to perform specific tasks or overtime (Berg et al., 2004; Nijp, Beckers, Geurts, Tucker, \& Kompier, 2012). While control over scheduling has been associated with better work-family balance (Beutell, 2010; Fenwick \& Tausig, 2001; Nijp et al., 2012), it can also improve work outcomes for employers, as it provides employees with resources to plan for and cope with job demands (Hurtado, Berkman, Buxton, \& Okechukwu, 2016; Richman, Civian, Shannon, Hill, \& Brennan, 2008).

By focusing on employees' ratings of their work-time control, our approach recognizes the power relations underlying work-time arrangements and so offers more-telling insight into the benefit of arrangements to worker well-being, family, and other areas of life (Beutell, 2010; Fenwick \& Tausig, 2001; Kelly \& Moen, 2007; McCrate, 2012). Focusing on employee control over work-time allows us to focus on employees' overall subjective experience of formal and informal scheduling arrangements, in contrast to other studies that have focused on employees' use of formal arrangements, such as flexible working times (Shockley \& Allen, 2012), part-time work (Lewis \& Humbert, 2010); and shift work (Henly, Shaefer, \& Waxman, 2006). Our focus on employee control avoids assuming that the presence of flexible work arrangements in an organization is necessarily positive but, rather, recognizes that employees may experience flexible arrangements in different ways and may benefit from arrangements to different extents (Hill et al., 2008; McCrate, 2012).

The analysis focuses on the organizational, occupational, employment, and personal characteristics influencing work-time control among Australian employees in the human services, defined broadly as the health, education, and social assistance industries. We therefore focus on the factors affecting work-time in a context in which much female employment is concentrated; public, private, and notfor-profit organizations compete for women's labor; and requirements for face-to-face service delivery in social services, schools, hospitals, and other institutional contexts may be perceived by managers as reasons to curtail employees' control over their work-time. Although we include men in our analysis, the focus is primarily on women, as they constitute the majority of employees in human service industries and generally carry greater domestic and care responsibilities than men, making control over work-time particularly significant for personal and family wellbeing outcomes. Women's experiences of work-time control are also of interest because while women shoulder most caregiving burden, they are more likely than men to work in positions that offer limited 
opportunities for employee-controlled flexibility and tend to have less leverage to influence their employment conditions (Swanberg, Pitt-Catsouphes, \& Drescher-Burke, 2005; Sweet et al., 2014).

\section{Work-time in the human services}

For the purposes of the study, human service industries are defined broadly to incorporate the health, education, and social assistance industries, which are concerned with nurturing and promoting growth and well-being and are female-dominated. The human services include the professional jobs of social work, nursing, and teaching and lower-status "pink-collar" personal-care occupations in aged care, child care, and disability services and a range of clerical, management, and other roles that do not require face-to-face contact with students, clients, or patients. However, the high proportion of staff who work directly with others can make the human services a particularly difficult context in which to implement employee-driven flexibility (Brescoll, Glass, \& Sedlovskaya, 2013; McMenamin, 2007; Skinner \& Chapman, 2013). As Sweet et al. (2014) point out that while industries relying on highly skilled workers can be expected to offer a wider range of options for flexible work arrangements where production is on site, such as in hospitals, schools, or care facilities, options may be limited.

Assessing levels of employee control in this set of industries also provides a way to assess the occupational influences over work-time among human service workers. The female dominated profession of teaching, for example, may be considered to provide opportunities for work-life balance because there is generally more consistency between teachers' face-to-face work-time and children's daily scheduling than in other jobs, enabling working parents to be available after school and during school holidays. However, although there is much variation in how teaching work is organized in different schools or other contexts, the face-to-face time teachers must spend with students on site means they have minimal control over work-time scheduling and locations compared with employees in other occupations. This makes it difficult to adjust work times to attend to nonwork responsibilities. Further, as Drago (2001) pointed out, "ideal worker" norms are entrenched in teaching, as teachers face intense and gendered pressures to care for children, underpinning expectations that they will work longer hours to provide extracurricular activities (Drago, 2001). Williamson, Cooper, and Baird (2015) point to the limited opportunities for flexible work arrangements in the teaching profession, particularly in relation to scheduling, and document career penalties incurred by women from the use of job-sharing arrangements including expanded workloads and limited career prospects.

In contrast to teaching, nursing is a 24-hour occupation performed in hospitals as well as other institutions and community-based settings. It is frequently managed through irregular scheduling, such as shift work (e.g., night shifts, split shifts), and temporary agency employment, primarily to ensure that patients' needs are met around the clock, but shift work may also enable nurses to achieve work-family reconciliation (Maher, Lindsay, \& Bardoel, 2010; Underhill, 2005). While this model of scheduling has underpinned assumptions that nursing is family friendly, irregular scheduling does not necessarily indicate work-time control as employees may have limited control over the shifts they work. Employers may allocate work inflexibly through set shifts, for example, and workers may find that shift times conflict with school or child-care hours or partners' working hours (Lindsay \& Maher, 2014; Lindsay, Maher, \& Bardoel, 2009; Maher et al., 2010).

Although it may be difficult to implement arrangements that allow human service workers to control their work-time given the demands of working with clients, research has started to elucidate the importance of flexibility in these contexts for service effectiveness. Job control-incorporating both how work is performed and when-has been found to help frontline care workers minimize workrelated stress, for example, and also to more effectively respond to the complex needs of children 
and the elderly, sick, or other vulnerable populations (for a review, see Cortis \& Eastman, 2015). In a study of 30 nursing homes, Hurtado et al. (2016) found aged-care workers used their schedule control in the interests of clients, with self-reported measures of schedule control predicting better well-being of nursing-home residents, indicated by lower prevalence of pressure ulcers. As such, allowing some human service workers, such as those providing aged care, to have some control over their work scheduling may enable them to schedule their work-time and tasks in ways that respond to client needs and that improve service quality.

\section{Work-time in the public, private, and nonprofit sectors}

As well as incorporating many female-dominated occupations for which client contact requirements have tended to make it difficult for employees to control their work-time, human service industries are of interest because in these industries, public, nonprofit, and for-profit organizations provide broadly similar kinds of services and compete for women's labor (Weisbrod, 1983). As public and nonprofit organizations tend to operate in a fairly narrow range of industries, the human services are the only area of the labor market where employees can plausibly choose between employment in public, private, or nonprofit organizations. Institutional theory suggests that organizations that operate in similar industry and sectoral contexts respond to a similar mix of employee values and motivations, governance arrangements, and sources of finance and constituent accountabilities and, as such, configure their human resource practices and standards, including work-time arrangements, in ways that correspond to those in similarly situated organizations (Cunningham, 2001; Parry, Kelliher, Mills, \& Tyson, 2005; Sweet et al., 2014). This suggests there may be differences in worktime practices as well as other employment characteristics across the sectors, for both individuals and occupational groups. However, comparisons of employment arrangements and conditions across the public, for-profit, and not-for-profit sectors have tended to focus on pay, with only a few studies exploring whether and how work-time dynamics, including employee control over worktime, varies across the sectors (McNamara, Brown, \& Pitt-Catsouphes, 2012).

Parry et al. (2005) compared nonprofit and public sector employment in the UK and observed the nonprofit sector offering a wider range of flexible work arrangements. Flexi-time, part-time work, job sharing, and home working were used to attract and retain workers where lack of funding restricted nonprofits' capacity to offer higher levels of pay (Parry et al., 2005). McNamara et al. (2012) explored whether motivations for employers to offer flexible work arrangements differed across public, private, and nonprofit organizations and found that financial considerations, such as the cost of implementing flexible work arrangements and the returns that could be expected for the organization, were more important in the decision-making of private sector employers, compared with public or nonprofit employers.

Overall however, research into work-time arrangements across the sectors is sparse. Wider comparisons of employment across the sectors have tended to compare two sectors only, often excluding the nonprofit or public sector, or conflating nonprofit and private sector employment (e.g., Benz, 2005; Leete, 2001). Comparisons have focused on monetary rewards (Weisbrod, 1983) or job satisfaction as a proxy for nonmonetary utility (Benz, 2005), with little focus on work-time arrangements. In addition, cross-sectoral comparisons of employment outcomes have not consistently accounted for the narrow range of industries in which nonprofit and public organizations are concentrated, nor for relevant individual, organizational, and industry factors (Gregory \& Milner, 2009).

Our sample, described in more detail later, is limited to employees in the human service industries in Australia. In Australia, as in other liberal welfare states, managing work-time around family and other responsibilities is a largely private, rather than state, responsibility (Orloff, 2009; Pocock, 
2005). Work hours for full-time workers are high by OECD standards, which combined with the high incidence of part-time work among women underpins large differences in men's and women's working arrangements and highly gendered household labor divisions and sizeable gender wage gaps (Barns \& Preston, 2010; Craig \& Mullan, 2010; Pocock, Skinner, \& Ichii, 2009).

Historically, Australia's system of industry-based awards regulated total weekly working hours and when work was performed through the day and week, with collective bargaining outcomes determined through compulsory federal and state arbitration (Berg et al., 2004). Since the 1990s, enterprise bargaining has expanded, such that around $44 \%$ of Australian workers now have their wages and conditions set at levels above minimum "safety net" standards at the enterprise rather than industry level (ABS, 2015). Since 2010, minimum standards have included the right to request flexible work for parents, carers, employees with a disability, and older employees, although requests can be refused by employers on reasonable business grounds (Cooper \& Baird, 2015). While this is a national standard that sets a safety net for all employees, the distribution of flexible work arrangements may be uneven among and within organizations and industries, depending on bargaining outcomes and differences in organizational and managerial cultures. For this reason, our analysis explores differences in work-time control among public, private, and nonprofit employees and among workers in different occupations, within Australia's human service industries, but due to data limitations, we cannot estimate the full range of firm-level factors that would shape employees' control over their work-time. Recognizing that work-time arrangements will be shaped by similar regulatory demands and constraints in each sector and the occupational composition of public, private, and nonprofit organizations, we expect levels of work-time control to differ across the sectors.

\section{Public sector}

Traditionally, public sector organizations have been understood as a source of quality jobs and as model employers of women, especially in health, education, and social care (Rubery, 2013). Promoting public sector employment has been widely seen as a way to promote gender equality, facilitating women's access to equal pay, merit-based career progression, job security, and comprehensive equity and diversity protections (Gornick \& Jacobs, 1998). Public sector organizations can be expected to provide more support for employees to adopt flexible work arrangements, due to their public visibility and likelihood of being evaluated against government standards (Den Dulk \& Groeneveld, 2013).

Public sector employment could therefore be expected to provide employees, and women in particular, with superior opportunities for work-time control. Public sector agencies were among the first to respond to the needs arising from the increased labor force participation of working mothers, being early adopters of flexible, compressed, and part-time schedules and opportunities to work at home, in some cases serving as models for private business (Saltzstein, Ting, \& Saltzstein, 2001). On this basis, human service employees may be expected to have more opportunity to control their work-time arrangements in the public sector compared with the private and not-for-profit sectors. However, there is likely to be much variation within the public sector. Den Dulk and Groeneveld (2013) found that in the European public sector, "public administration organizations" (ministries, federal bodies, local authorities) were more likely to offer flexible work arrangements than welfare state public organizations (i.e., those in health, social work, education) most likely because of the face-to-face work required in schools, hospitals, or other institutional workplaces. These researchers also found that larger public organizations and those with higher proportions of female employees offered a greater range of flexible work arrangements. 
On the other hand, public sector models of work-life reconciliation have been criticized. It has been argued for example that notions of the public sector as a model employer of women are based on the traditional elements of public sector human resource policy, such as pay, job security, and retirement benefits rather than flexible work arrangements (Kim \& Wiggins, 2011). Public employers have been criticized for being relatively slow to introduce opportunities for employees to control their work-time arrangements (Kim \& Wiggins, 2011). Glauber (2011), for example, challenged notions that female-dominated-public sector jobs offer greater flexibility, finding that unlike other types of family friendly benefits (like paid parental leave and onsite child care), public sector jobs offer worse access to flexible work arrangements in the United States. Similarly, Golden (2008) found that government employment, particularly at the local level, reduced employees' access to flexible work arrangements. Interestingly however, this was largely due to the particular type of occupations present in each sector, underlining the importance of controlling for occupation in studies of work-time and of interacting occupational and sectoral measures.

\section{Not-for-profit sector}

Not-for-profit organizations offer environments that could also be expected to offer good opportunities for women to control their working hours. Nonprofit employees tend to be more satisfied than others with their jobs overall (Benz, 2005; Donegani, McKay, \& Moro, 2012), and their satisfaction with flexible work arrangements has been widely interpreted as one of the "compensating differentials" that makes up for the lower levels of pay they receive (Andreoni, 1990; Handy \& Katz, 1998; Hansmann, 1980; Mosca, Musella, \& Pastore, 2007). Compared with the public sector, nonprofits tend to be less bureaucratized and have more-fluid role expectations, which may give employees opportunities for higher levels of control over their work arrangements. Nonprofits are less likely to have formal policies and procedures in place for regulating work-time and fewer layers of managerial hierarchy, giving employees more scope to control their own working arrangements (LeRoux \& Feeney, 2013).

In addition, the social movement, voluntary origins, and justice-focused missions of many nonprofits could be expected to translate into egalitarian approaches to decision making, including those involving employment conditions and schedules (Haley-Lock, 2009). Indeed, Donegani et al. (2012) found that workers in nonprofit organizations tend to have greater autonomy and involvement in the running of their organizations than those in the private and public sectors, which may be associated with higher levels of work-time control.

On the other hand, resource scarcities, a lack of economies of scale, and limited access to human resource management expertize can yield minimalist approaches to compensation and flexible work arrangements in the nonprofit sector (Haley-Lock, 2009). Although nonprofit organizations are often argued to be flexible, dynamic, and innovative (Forth, Bryson, \& Bewley, 2006), since the 1980s, nonprofits in many countries have been subject to privatization, decreased funding, increased service demand, the erosion of professional autonomy, and new managerial models (Baines, 2011; Evans, Richmond, \& Shields, 2005). For employees, these structural challenges have been argued to lengthen working hours, reduce employment numbers, and erode wages and working conditions (Baines, 2004, 2010; McDonald, 2006). The social services sector, for example, is increasingly characterized by flexible staffing arrangements, lean shifts, split shifts, and part-time, contract, casual, and other forms of temporary work (Baines, 2011), which may make it challenging for employees to retain work-time autonomy. However, while resource constraints may undermine nonprofits' capacity to invest resources in promoting flexible work arrangements, organizations may attempt to make up for lower pay and benefits by offering such arrangements (Matz-Costa \& PittCatsouphes, 2009). 


\section{Private sector}

In the private sector, discourses of gender equity or neutrality have become increasingly common in human resource departments and diversity initiatives, at least in larger organizations. However, these usually coexist with business-focused discourses that position those who deviate from the traditional male model of work and careers as problematic (Kugelberg, 2006; Lewis \& Humbert, 2010). Golden and Wiens-Tuers (2006) suggests that profit-focused employers are more likely to require their employees to work longer hours than they might prefer, although Dex and Bond (2005) found that private sector employees did not have systematically less work-life balance than public sector employees. Workplaces that privilege "ideal worker" models are also likely to reward compliance and penalize noncompliance (Drago, Wooden, \& Black, 2009). This may explain why the take-up of flexible work arrangements is lower than the availability of such arrangements in the private sector (Powell \& Zhu, 2014), demonstrating that it is insufficient to examine only the presence of flexible-work policies in private companies. For example, in Australia, $44.5 \%$ of public sector employees have some say in their start/finish times, compared to only $38.4 \%$ of private sector employees (ABS, 2012). Further, since private sector employees often have less job security than employees in the public sector, they may have less bargaining power for workplace entitlements, including flexible work arrangements (Drago et al., 2009; Kalleberg \& Mastekaasa, 1998).

\section{Methods}

To explore the factors affecting schedule control for employees in public, private, and nonprofit human service organizations, we analyzed data from the Household Income and Labour Dynamics in Australia (HILDA). HILDA is a large-scale longitudinal panel survey of a nationally representative sample of households. HILDA collects data about individuals and their households, relating to economic and subjective well-being and labor-market and family dynamics. It is particularly valuable for its detailed information about employment conditions and employee well-being. The first wave of HILDA was conducted in 2001 with annual waves thereafter. Although the longitudinal dimensions of the survey could be used to explore the impact of employee control over time, our analysis instead has more focused aims, attempting to use HILDA to analyze the factors associated with levels of employee control over work-time. As such, our analysis uses data from one wave only: Wave 12, which was collected in 2012 and consisted of approximately 17,500 respondents from 9,500 households. 2 Using unweighted data, we limited our sample to women and men receiving wages/salary, who usually worked some hours each week and who were of prime working age (21to 60-years old). Those in human services industries only were selected, defined as education, health care, and social assistance, using national industry classifications. 3 This provided a total sample size of 1,636 women and 464 men. Information about the sample is detailed in Table 1. More than half of women and men in the sample worked in the public sector (53.4\% and $56.0 \%$, respectively), reflecting the importance of government policy, administration, and provision in education, health, and social services.

The sample description shows that men were much more likely than women to have a tertiary degree (i.e., an undergraduate or postgraduate qualification from a university or college) and were more than twice as likely to be employed in a managerial occupation. Men were less likely than women in the sample to be employed as nurses or personal care workers and to work in small workplaces and on a part-time basis. Men also averaged longer weekly work hours (38.3 compared to 31.8) and higher hourly wages (AU\$34.47 compared to AU\$30.46). 
Table 1. Sample (percent, unless otherwise stated)

\begin{tabular}{|c|c|c|c|c|c|c|c|c|}
\hline & \multicolumn{4}{|c|}{ Women } & \multicolumn{4}{|c|}{ Men } \\
\hline & $\begin{array}{c}\text { All } \\
\text { sectors }\end{array}$ & Private & Public & $\begin{array}{l}\text { Not-for- } \\
\text { profit }\end{array}$ & $\begin{array}{c}\text { All } \\
\text { sectors }\end{array}$ & Private & Public & $\begin{array}{l}\text { Not-for- } \\
\text { profit }\end{array}$ \\
\hline Total & 1636 & 372 & 874 & 386 & 464 & 94 & 260 & 110 \\
\hline \multicolumn{9}{|l|}{ Personal characteristics } \\
\hline Mean age (years) & 42 & 40 & 42 & 42 & 41 & 38 & 42 & 41 \\
\hline $\begin{array}{l}\text { Child under } 14 \text { in the } \\
\text { household }\end{array}$ & 37.2 & 36 & 39 & 34.7 & 36.9 & 35.1 & 37.3 & 37.3 \\
\hline Has a tertiary degree & 49.9 & 36 & 59.2 & 43 & 61.2 & 45.7 & 71.2 & 50.9 \\
\hline Occupational characteristics & $\hat{A}$ & $\hat{A}$ & $\hat{A}$ & $\hat{A}$ & $\hat{A}$ & $\hat{A}$ & $\hat{A}$ & $\hat{A}$ \\
\hline Managers & 4.6 & 4.8 & 3.7 & 6.5 & 11.4 & 10.6 & 11.2 & 12.7 \\
\hline Teachers & 27.4 & 11.3 & 37.9 & 19.4 & 31 & 14.9 & 39.6 & 24.5 \\
\hline Nurses & 15.5 & 18.3 & 17.6 & 8.3 & 4.5 & 2.1 & 5.8 & 3.6 \\
\hline Personal-care workers & 10.3 & 13.2 & 5.6 & 18.1 & 7.1 & 7.4 & 4.6 & 12.7 \\
\hline Other occupations & 42.2 & 52.4 & 35.2 & 47.7 & 45.9 & 64.9 & 38.8 & 46.4 \\
\hline $\begin{array}{l}\text { Employment characteristics } \\
\text { Small workplace (less than }\end{array}$ & $\hat{A}$ & $\hat{A}$ & $\hat{A}$ & $\hat{A}$ & $\hat{A}$ & $\hat{A}$ & $\hat{A}$ & $\hat{A}$ \\
\hline $\begin{array}{l}\text { 20employees at place of } \\
\text { work) }\end{array}$ & 24.9 & 46.5 & 13.2 & 30.1 & 16.2 & 31.9 & 9.2 & 19.1 \\
\hline Part-time & 46.8 & 52.2 & 43.7 & 48.7 & 17 & 22.3 & 13.5 & 20.9 \\
\hline Casual & 16 & 28.5 & 11.3 & 14 & 14.9 & 25.5 & 10.4 & 16.4 \\
\hline $\begin{array}{l}\text { Irregular work schedule } \\
\text { (varies week by week or } \\
\text { month bymonth) }\end{array}$ & 16.7 & 16.1 & 17.8 & 14.8 & 16.2 & 17 & 14.6 & 19.1 \\
\hline Trade union member & 38.9 & 19.9 & 52.5 & 26.8 & 35.1 & 11.7 & 48.5 & 23.6 \\
\hline $\begin{array}{l}\text { Mean hourly wage (AU\$) } \\
\text { (winsorized) }\end{array}$ & $\$ 30.46$ & $\$ 27.56$ & $\$ 32.82$ & $\$ 28.03$ & $\$ 34.47$ & $\$ 31.62$ & $\$ 36.49$ & $\$ 32.14$ \\
\hline $\begin{array}{l}\text { Mean weekly work hours } \\
\text { (SD) }\end{array}$ & $\begin{array}{c}31.8 \\
(12.6)\end{array}$ & $\begin{array}{c}29.7 \\
(12.6)\end{array}$ & $\begin{array}{c}32.9 \\
(12.9)\end{array}$ & $\begin{array}{c}31.3 \\
(11.9)\end{array}$ & $\begin{array}{c}38.3 \\
(12.2)\end{array}$ & $\begin{array}{c}35.8 \\
(12.9)\end{array}$ & $\begin{array}{c}39.3 \\
(11.5)\end{array}$ & $\begin{array}{c}38.0 \\
(13.1)\end{array}$ \\
\hline
\end{tabular}

Across the sectors, lower-than-average proportions of men and women were employed on a casual4 (rather than permanent or fixed term) basis in the public sector. Higher-than-average proportions of private sector respondents in the sample worked casually. Part-time employment (less than 35 hours a week) was highest for both women and men in the private sector ( $52.2 \%$ and $22.3 \%$, respectively) and lowest in the public sector ( $43.7 \%$ and $13.5 \%$, respectively). Public sector workers were less likely than others to be employed in small workplaces, defined as those with less than 20 employees. Across all sectors, men were more likely than women to be in managerial occupations $(11.4 \%$ compared with $4.6 \%$ ). Among women, those in the public sector were less likely to be in managerial occupations than women in private or nonprofit organizations, while men employed in the private sector were least likely to be in managerial occupations.

Teachers in the sample were concentrated in the public sector, with the low proportion of teachers in the private sector likely reflecting how in Australia, private primary and high schools are defined as nongovernment schools and constitute not-for-profit organizations. Personal-care workers, defined as those who provide routine personal care such as feeding and bathing to people in residential care facilities or in private homes, were concentrated in the not-for-profit sector. Public sector workers were most likely to have a tertiary degree and to be trade union members. Average incomes were higher for public sector employees than for employees in other sectors as were mean weekly work hours. 


\section{Analysis plan}

We present two linear regression models to examine whether public, nonprofit or for-profit employment offer employees the best prospects to control their work-time, accounting for other occupational, employment and personal characteristics.

\section{Dependent variables}

Control over work-time is a derived measure combining responses to the three survey questions: "I have a lot of freedom to decide when I do my work"; "my working times can be flexible"; and "I can decide when to take a break." Our approach follows other studies that have used average scores across specific subdimensions of work-time control. A systematic review showed that of 63 relevant papers on work-time control, 31 assessed it using a global construct that asked employees, in general, how much control they had in deciding when they performed their job, while 13 took the approach similar to ours, of aggregating average scores tested for scale reliability across specific subdimensions of work-time control (Nijp et al, 2012).5

In HILDA, respondents were asked to rate their level of agreement or disagreement with the three statements on work-time control on a seven-point scale, where 1 indicated strong disagreement and 7 indicated strong agreement. The derived variable was calculated as the mean score across the three items, 6 with a Cronbach's alpha of 0.81 indicating high scale reliability. The measure was normally distributed with measures of kurtosis and skewness falling between -1 and 1 .

\section{Independent and control variables}

The key independent variables captured whether or not respondents worked in the private for-profit or nonprofit sectors, to help overcome the paucity of knowledge about the extent to which employment across the sectors differs in terms of work-time control.

As control over work-time and access to alternative working arrangements may be influenced by occupation (Golden, 2008; Stein, 2015), we controlled for the main human service occupations, using national occupational classifications ( $A B S, 2006 a$ ). Four dummy variables (yes $=1$, no $=0$ ) captured whether or not respondents were managers $(n=128)$; teachers or other educators $(n=$ $592)$; nurses or midwives $(n=275)$; or personal support workers $(n=202) .7$ Other respondents $(n=$ 903) were from a diverse range of occupations, including receptionists and clerical workers, welfare support workers, child carers, and program and project administrators.

As well as sector and occupation, the models controlled for personal, workforce, and workplace characteristics shown in other research to be associated with flexible work arrangements and job control and which could therefore have confounding effects on our dependent variable. As research has found that the number of employees or size of the workplace is positively associated with support for flexible work arrangements (Den Dulk \& Groenveld, 2013), our models control for whether or not employees worked in a small workplace, defined as having less than 20 employees. We also included dummy variables to control for part-time hours (less than 35 hours per week), casual employment, and irregular scheduling (yes $=1$, no $=0$ ), on the basis that these may have independent associations with employee perceptions of control (Golden, 2008).8 Personal factors that may impact on individuals' needs and desire for flexible work arrangements were also entered in the models, including age, tertiary-degree-level qualification, and presence of a child under 14 in the household (Golden, 2008; Hill et al., 2008; Peters, Den Dulk, \& Van Der Lippe, 2009; Shockley \& Allen 2012). Trade union membership was included on the basis that unions can influence organizations to implement work-time practices that benefit employees (Berg et al., 2004; McCurdy, 
Newman, \& Lovrich, 2002), although unions may also resist individual flexibility initiatives as contrary to aims of collective time regulation (Sweet et al., 2014).9 The reference category in the models therefore consisted of permanent full-time, nonmanagerial, nonunion, public sector employees working in large workplaces.

Model 2 repeats Model 1, but with interaction terms for sector and the main human service occupations. Including interactions enables the analysis in Model 2 to delve deeper, to explore whether and how levels of work-time control differ for the main human service occupations in each sector. Thus, as well as accounting separately for occupation and sector, our analysis accounts for the possibility that workers in a particular occupational group may have different levels of control over their work-time when employed in the public, private, and nonprofit sectors.

\section{Findings}

Model 1 (Table 2) used linear regression methods to identify the extent to which working in the nonprofit and private sectors influenced employees' perceived level of control over their work-time when controlling for employment, occupational, and personal characteristics. Working in the nonprofit sector was found to have an independent, positive association with human service workers' control over their work-time compared with public sector employment, while private employment had no effect. Being male was associated with higher levels of control over work-time. Control over work-time was also positively associated with hourly wages and with having a tertiary degree. Being a trade union member, working an irregular schedule, and working in the main human service occupations of nursing, teaching, and personal care were associated with lower control over work hours. However, the negative effect was largest for teachers, presumably because of the rigid scheduling of school time (Drago, 2001; Williamson et al., 2015).

Model 2, which incorporates the interactions, further shows the effects of sector for the main occupational groups (Table 2). Compared with Model 1, sector differences in employees' perceptions of control over work-time were stronger in Model 2. This more comprehensive model predicts that employees in the nonprofit sector will have significantly higher levels of control over work-time than public sector employees, with private sector employees having significantly lower levels of control over work-time. Among occupation groups, control over work-time is highest among managers and "other" occupations (our reference category), a category that includes a mix of child carers, receptionists and clerical workers, welfare support workers, program and project administrators, and office managers. Again, control over work-time was lowest among teachers, which, as noted above, likely reflects fixed school times.

The interaction effects in Model 2 demonstrate that while workers in managerial occupations have high levels of autonomy relative to other human service workers, managers' average level of control over work-time is significantly higher in the private sector than in the public sector. Among teachers, work-time control is significantly lower in the not-for-profit compared to public sector and is significantly higher in the private sector, although as noted earlier, private sector teachers are more likely to be working outside of schools, as private (nongovernment) schools are formally constituted as not-for-profit organizations in Australia. Among nurses we found no significant difference in worktime control between sectors, suggesting that levels of work-time control are defined by occupational norms and characteristics other than sector. For personal-care workers, control over work-time was found to be significantly lower in the nonprofit sector than in the public sector. The implications of this finding warrant further exploration at a time that much Australian public sectorhome-care work is being transferred to the nonprofit and private sectors, including as a result of outsourcing state home-care programs and the introduction of consumer-directed funding initiatives 
in disability and aged care. All other control variables were found to have similar effects across Models 1 and 2.

Table 2. Linear regression models: control over their work-time

\begin{tabular}{|c|c|c|c|c|}
\hline & \multicolumn{2}{|c|}{ Model 1} & \multicolumn{2}{|c|}{ Model 2} \\
\hline & $\beta$ & SE & $\beta$ & SE \\
\hline \multicolumn{5}{|l|}{ Gender } \\
\hline Men & $0.26^{* *}$ & 0.09 & $0.27 * *$ & 0.09 \\
\hline \multicolumn{5}{|l|}{ Sector } \\
\hline Nonprofit sector & $0.20 *$ & 0.09 & $0.44^{* * *}$ & 0.13 \\
\hline Private sector & -0.16 & 0.1 & $-0.32 *$ & 0.14 \\
\hline \multicolumn{5}{|l|}{ Occupational characteristics } \\
\hline Manager & 0.23 & 0.16 & 0.12 & 0.22 \\
\hline Teacher & $-1.62 * * *$ & 0.09 & $-1.61 * * *$ & 0.12 \\
\hline Nurse & $-0.40 * *$ & 0.13 & $\hat{a}^{\wedge \prime} 0.30 x$ & 0.16 \\
\hline Personal-care worker & $-0.36^{* *}$ & 0.13 & -0.01 & 0.23 \\
\hline \multicolumn{5}{|l|}{ Interactions } \\
\hline Manager*NFP & & & 0.48 & 0.34 \\
\hline Manager*Private & & & $0.80 *$ & 0.39 \\
\hline Teacher*NFP & & & $-0.53^{*}$ & 0.22 \\
\hline Teacher*Private & & & $0.71^{* *}$ & 0.26 \\
\hline Nurse*NFP & & & -0.51 & 0.33 \\
\hline Nurse*Private & & & -0.01 & -0.27 \\
\hline Personal-care worker*NFP & & & $-0.95 * *$ & 0.3 \\
\hline Personal-care worker*Private & & & 0.12 & 0.33 \\
\hline \multicolumn{5}{|l|}{ Employment characteristics } \\
\hline Small workplace (< 20 employees) & 0.02 & 0.09 & 0.03 & 0.09 \\
\hline Part-time & 0.1 & 0.08 & 0.1 & 0.08 \\
\hline Casual & $0.19 x$ & 0.11 & 0.17 & 0.11 \\
\hline Irregular schedule & $-0.23^{*}$ & 0.11 & $-0.24^{*}$ & 0.11 \\
\hline Belongs to a trade union & $-0.49 * * *$ & 0.08 & $-0.48 * * *$ & 0.08 \\
\hline Hourly wage (winsorized) & $0.03 * * *$ & 0 & $0.03^{* * *}$ & 0 \\
\hline \multicolumn{5}{|l|}{ Personal characteristics } \\
\hline Age last birthday & -0.00 & 0.03 & -0.00 & 0.03 \\
\hline Age squared & 0 & 0 & 0 & 0 \\
\hline Child under 14 in the household & 0.07 & 0.09 & 0.07 & 0.09 \\
\hline Has a tertiary degree & $0.20 *$ & 0.08 & $0.22 * *$ & 0.08 \\
\hline Constant & $3.03 * * *$ & 0.55 & $3.04 * * *$ & 0.55 \\
\hline Adjusted $r$ squared & 0.23 & & 0.24 & \\
\hline $\mathbf{N}$ & 1902 & & 1902 & \\
\hline
\end{tabular}

\section{Discussion and conclusions}

As previous research has shown, control over work-time shapes the extent to which employees benefit from flexible work arrangements, through better work-family balance and well-being 
(Donnelly et al., 2012; Fenwick \& Tausig, 2001; Hurtado et al., 2016; McCrate, 2012). We have built on this with a unique focus on the factors affecting work-time control in human service organizations, where many women perform face-to-face caring and nurturing roles. Whereas common measures of work-time arrangements assume employees benefit from variable hours or flexible work, our approach uses employees' own ratings of the extent to which they control their work-time. Focusing on employees' perceptions of their overall level of control over scheduling avoids assumptions of the benefits of formal flexible work arrangements. Furthermore, we explored the impact of working in the public, nonprofit and private sectors on control over work-time, and, by focusing on human services only, accounted for the narrow range of industries in which not-forprofit and public sector organizations operate. Our modeling also controlled for and interacted occupations, recognizing the different occupational compositions of the public, private, and nonprofit sectors, even within human service industries. This showed the varying prospects of the human service's main occupational groups to achieve work-time control in public, private, and notfor-profit contexts.

First, the analysis showed that among employees in human service industries, men have higher levels of work-time control on average than women, echoing previous research showing that men have better access to schedule control (Swanberg et al., 2005). As women face more domestic demands and are more likely than men to use flexible scheduling to promote family well-being outcomes, the finding that patterns of work-time control are highly gendered underlines the suboptimal distribution of this element of job quality (Baxter, 2002; Craig \& Bittman, 2008; Sang \& Powell, 2012). Human service managers can intervene to ensure not only that their organizations offer opportunities for employees to control their work-time arrangements but also that these opportunities are fairly distributed to female-dominated areas of the workforce, with any barriers to take-up or flexibility stigma addressed.

Further, the multivariate findings build evidence that sector shapes human service employees' control over their work-time. We found that nonprofit employment offers a modest but significant advantage in control over work-time, compared with public sector employment. Employees had greater likelihood of controlling their work-time in the nonprofit than in the public sector and the lowest prospects in the private sector. As suggested previously, higher perceptions of control over work-time may indicate that autonomy and flexibility are among the nonmonetary rewards that non profit employers use to attract and retain employees in lieu of pay (Andreoni, 1990; Mosca et al., 2007).

In a competitive labor market, where other organizational resources are constrained, offering opportunities for work-time control may improve the capacity of not-for-profit human service organizations to attract employees. Prospects to better balance work and family may be one factor contributing to the sector's feminized workforce profile. It may also be that not-for-profit organizations have flatter, less hierarchical structures that enable women more capacity to negotiate and exert control over their working arrangements than their public- and private sector counterparts (LeRoux \& Feeney, 2013), although this could not be specifically explored with the HILDA data.

While it may seem surprising that the public sector did not afford employees more control over work-time even after controlling for occupation, this may reflect some of the rigidity of employment arrangements and roles in the public sector, which are more centrally and tightly regulated than in other contexts. For example, public sector agencies may be subject to more political and managerial scrutiny and, as mostly large organizations, they may have more-formalized policies offering particular benefits and may offer less variation in terms and conditions of employment (Den Dulk \& Groeneveld, 2013; Kim \& Wiggins, 2011). Our findings suggest a need for public and private human 
service organizations in particular to focus on promoting work-time control. Schedule flexibility and employee work-time control should be considered alongside pay, leave, and other conditions as a strategy to attract and retain staff. To develop initiatives, case study evidence of good practice in enabling schedule control in face-to-face health, education, and welfare contexts would guide implementation by human service managers.

As well as exploring sector, our analysis showed how employees' levels of work-time control are influenced by other employment, occupational, and personal characteristics and their intersections (Hill et al., 2008). Occupation was found to be important. Notably, frontline occupations of nursing, teaching and personal-care work were associated with low work-time control, presumably because of the need to schedule work in ways that guarantee face-to-face services for students, patients, and clients (Drago, 2001; Lindsay \& Maher, 2014). Indeed, the findings show how higher levels of control over work-time arrangements tend to be found outside the large female-dominated occupations of teaching and nursing. Furthermore, the interactive models showed that sector had a different association with employees' control over work-time across occupations. Employees in managerial positions and those working outside teaching, nursing, and personal-care work were found to have higher levels of control over work-time than others, but work-time control was higher still if workers in these occupations were employed outside the public sector. Teachers had very low overall levels of work-time control relative to employees in other occupations, but their control over their worktime was higher in the private sector. This may be because this category consisted of the small number of teachers working outside of more rigidly scheduled public and nongovernment school contexts, such as private tutors.

Higher levels of work-time control among employees in managerial occupations, among those with tertiary-level education and with higher levels of remuneration may be because employers of these workers offer a greater range of flexible work arrangements than others. As suggested by Sweet et al. (2014), employers may use this strategy to attract highly skilled employees or, alternatively, higher skilled employees may have greater capacity to negotiate control over working time.

There are some limitations with our study. We have focused on employees' self-reported perceptions of the extent to which they can control their work scheduling. While, as we have argued, this is preferable to conventional measures of the presence of variable working hours, we need a much deeper understanding of how the work-time arrangements that enable employees, especially women, to control their circumstances, are negotiated between employees, supervisors, and employers and how these can be reinforced in organizational and public policy. Further research should explore negotiation of formal work-time arrangements and the outcomes of arrangements negotiated between supervisors and employees, including outcomes for service users. The HILDA data set does not provide information about employees' personal decision making about their worktime arrangements and when, how, and why they vary them, nor does it link working arrangements with client experiences and service delivery outcomes. Experiences of work-time may be better explored using qualitative methods such as in-depth interviews with employees, managers, and service users. Further work could also use the longitudinal capacity of HILDA and other panel data sets to link changes in working-time arrangements, perceived levels of control, and well-being outcomes across the life course. While our analysis is based on cross-sectional comparison only, it can nonetheless inform future inquiry by indicating the sectoral, occupational, and other employment features shaping work-time arrangements in the human services.

\section{Acknowledgments}

This paper uses unit record data from the Household, Income and Labour Dynamics in Australia (HILDA) survey. The HILDA project was initiated and is funded by the Australian Government 
Department of Social Services (DSS) and is managed by the Melbourne Institute of Applied Economic and Social Research (Melbourne Institute). The findings and views reported in this paper, however, are those of the authors and should not be attributed to either DSS or the Melbourne Institute.

\section{Funding}

This work was supported by an Australian Research Council Discovery Early Career Researcher Award (Project DE130100028).

\section{Notes}

1 Like Berg et al. (2004), our focus is on individual control rather than workers' collective control.

2 The Wave 1 (2001) household response rate was $66 \%$ and as a longitudinal survey, there was some attrition in subsequent years. In Wave 12, 96\% of individuals interviewed in Wave 11 were re-interviewed, and $88 \%$ returned the self-completion questionnaire in addition to completing an interview. More information about the survey structure and sampling is in Wilkins (2015, see pp. 91-94) and Melbourne Institute of Applied Economic and Social Research (2014).

3 These were defined as education and training (ANZSIC 8000-8299) and health care and social assistance (ANZSIC 8400-8799), see ABS (2006b).

4 Casual employees are defined as those without entitlement to either paid annual leave or paid sick leave, as per the primary measure of casual employment used by the Australian Bureau of Statistics and contained in the HILDA survey (Kryger, 2015).

5 Remaining studies examined specific subdimensions of work-time control only.

6 Missing values on any of the three items were imputed based on respondents' average scores on completed items.

7 The category of "managers" included all managers, including school principals and health and welfare managers (ANZSCO codes 1000 to 1499). The category of "teachers" included school, tertiary, and other education professionals such as private tutors and teachers of English to speakers of other languages as well as education aides (ANZSCO codes 2400-2493 and 4221). The category of "nurses" was defined as midwives and nursing professionals, as well as enrolled and mothercraft nurses (ANZSCO 2540-2544 and 4114). Personal support workers included aged and disabled carers, nursing support and personal care workers, and special care workers (ANZSCO codes 4230-4231 and 4233-4234).

8 These scheduling measures also differed across occupations in our sample. For example, whereas $48.4 \%$ of nurses and $35.6 \%$ of personal care workers had schedules that varied week to week or month to month, this was the case for less than $8.8 \%$ of human service workers in other occupations.

9 Employee control of working time may also be shaped by competitive conditions in the labor market, as excess demand or skill shortages can improve the bargaining position of employees seeking individual control. It may also be shaped by employer strategy, including managerial use of time arrangement to lower costs or increase efficiencies (Berg et al., 2004). As the HILDA survey did not capture labor market conditions or details of managerial approaches, these were not included.

\section{References}

ABS. (2006a). ANZSCO - Australian and New Zealand Standard Classification of Occupations. First Edition, 2006. Cat. no. 1220.0. Canberra, Australia: Australian Bureau of Statistics. 
ABS. (2006b). Australian and New Zealand Standard Industrial Classification (ANZSIC), 2006 (Revision 1.0). Cat. no. 1292.0. Canberra, Australia: Australian Bureau of Statistics.

ABS. (2012). Working time arrangements, Australia, November 2012. Cat. no. 6342.0. Canberra, Australia: Australian Bureau of Statistics.

ABS. (2015). Employee earnings and hours, Australia, May 2014. Cat. no. 6306.0. Canberra, Australia: Australian Bureau of Statistics.

Allen, T. D., Herst, D. E. L., Bruck, C. S., \& Sutton, M. (2000). Consequences associated with work-tofamily conflict: A review and agenda for future research. Journal of Occupational Health Psychology, 5(2), 278-308. doi:10.1037/1076-8998.5.2.278

Andreoni, J. (1990). Impure altruism and donations to public goods: A Theory of warm-glow giving. Economic Journal, 100(401), 464-477. doi:10.2307/2234133

Baines, D. (2004). Caring for nothing: Work organization and unwaged labour in social services. Work, Employment and Society, 18(2), 267-295. doi:10.1177/09500172004042770

Baines, D. (2010). "If we don't get back to where we were before": Working in the restructured nonprofit social services. British Journal of Social Work, 40(3), 928-945. doi:10.1093/bjsw/ben176

Baines, D. (2011). "It was just too hard to come back": Unintended policy impacts on work-family balance in the Australian and Canadian non-profit social services. Community, Work and Family, 14(2), 233-248. doi:10.1080/13668803.2011.571403

Barns, A., \& Preston, A. (2010). Is Australia really a world leader in closing the gender gap? Feminist Economics, 16(4), 81-103. doi:10.1080/13545701.2010.530607

Baxter, J. (2002). Patterns of change and stability in the gender division of household labour in Australia, 1996-1997. Journal of Sociology, 38(4), 399-424. doi:10.1177/144078302128756750

Beers, T. M. (2000). Flexible schedules and shift work: Replacing the "9-to-5" workday? Monthly Labor Review, 123(6), 33-40.

Benz, M. (2005). Not for the profit, but for the satisfaction? Evidence on worker well-being in nonprofit firms. Kyklos, 58(2), 155-176. doi:10.1111/kykl.2005.58.issue-2

Berg, P., Appelbaum, E., Bailey, T., \& Kalleberg, A. (2004). Contesting time: International comparisons of employee control of working time. Industrial and Labor Relations Review, 57(3), 331-349. doi:10.1177/001979390405700301

Berg, P., Bosch, G., \& Charest, J. (2014). Working-time configurations: A framework for analyzing diversity across countries. ILR Review, 67(3), 805-837. doi:10.1177/0019793914537452

Beutell, N. J. (2010). Work schedule, work schedule control and satisfaction in relation to workfamily conflict, work-family synergy, and domain satisfaction. Career Development International, 15(5), 501-518. doi:10.1108/13620431011075358

Brescoll, V. L., Glass, J., \& Sedlovskaya, A. (2013). Ask and ye shall receive? The dynamics of employer-provided flexible work options and the need for public policy. Journal of Social Issues, 69(2), 367-388. doi:10.1111/josi.2013.69.issue-2

Carlson, D., Grzywacz, J., \& Kacmar, K. (2010). The relationship of schedule flexibility and outcomes via the work-family interface. Journal of Managerial Psychology, 25(4), 330-355. doi:10.1108/02683941011035278 
Chung, H., \& Tijdens, K. (2013). Working time flexibility components and working time regimes in Europe: Using company-level data across 21 countries. International Journal of Human Resource Management, 24(7), 1418-1434. doi:10.1080/09585192.2012.712544

Cooper, R., \& Baird, M. (2015). Bringing the "right to request" flexible working arrangements to life: From policies to practices. Employee Relations, 37(5), 568-581. doi:10.1108/ER-07-20140085

Cortis, N., \& Eastman, C. (2015). Is job control under threat in the human services? Evidence from frontline practitioners in Australia, 2003-2012. Competition and Change, 19(3), 210-227. doi:10.1177/1024529415580260

Craig, L., \& Bittman, M. (2008). The incremental time costs of children: An analysis of children's impact on adult time use in Australia. Feminist Economics, 14(2), 59-88. doi:10.1080/13545700701880999

Craig, L., \& Mullan, K. (2010). Parenthood, gender and work-family time in USA, Australia, Italy, France and Denmark. Journal of Marriage and Family, 72(5), 1344-1361. doi:10.1111/j.17413737.2010.00769.x

Cunningham, I. (2001). Sweet charity! Managing employee commitment in the UK voluntary sector. Employee Relations Journal, 23(3), 226-240. doi:10.1108/01425450110392616

Daly, T. (2014). Evenings, nights and weekends: Working unsocial hours and penalty rates. Adelaide, Australia: Centre for Work + Life, University of South Australia.

Den Dulk, L., \& Groeneveld, S. (2013). Work-life balance support in the public sector in Europe. Review of Public Personnel Administration, 33(4), 384-405. doi:10.1177/0734371X12449024

Dex, S., \& Bond, S. (2005). Measuring work-life balance and its covariates. Work, Employment and Society, 19(3), 627-637. doi:10.1177/0950017005055676

Donegani, C., McKay, S., \& Moro, S. (2012). A dimming of the "warm glow"? Are non-profit workers in the UK still more satisfied with their jobs than other workers? In A. Bryson (Ed.), Advances in the economic analysis of participatory and labor-managed firms volume 13 (pp. 313-342). Bingley, UK: Emerald Group Publishing.

Donnelly, N., Proctor-Thomson, S. B., \& Plimmer, G. (2012). The role of "voice" in matters of "choice": Flexible work outcomes for women in the New Zealand public services. Journal of Industrial Relations, 54(2), 182-203. doi:10.1177/0022185612437843

Drago, R. (2001). Time on the job and time with their kids: Cultures of teaching and parenthood in the US. Feminist Economics, 7(3), 1-31. doi:10.1080/13545700152726859

Drago, R., Wooden, M., \& Black, D. (2009). Long work hours: Volunteers and conscripts. British Journal of Industrial Relations, 47(3), 571-600. doi:10.1111/bjir.2009.47.issue-3

Evans, B., Richmond, T., \& Shields, J. (2005). Structuring neoliberal governance: The nonprofit sector, emerging new modes of control and the marketisation of service delivery. Policy and Society, 24(1), 73-97. doi:10.1016/S1449-4035(05)70050-3

Fenwick, R., \& Tausig, M. (2001). Scheduling stress: Family and health outcomes of shift work and schedule control. American Behavioral Scientist, 44(7), 1179-1198. doi:10.1177/00027640121956719

Forth, J., Bryson, A., \& Bewley, H. (2006). Small and medium-sized enterprises: Findings from the 2004 workplace employment relations survey. London, UK: Department of Trade and Industry. 
Glauber, R. (2011). Limited access: Gender, occupational composition, and flexible work scheduling. Sociological Quarterly, 52, 472-494. doi:10.1111/tsq.2011.52.issue-3

Golden, L. (2008). Limited access: Disparities in flexible work schedules and work-at-home. Journal of Family and Economic Issues, 29(1), 86-109. doi:10.1007/s10834-007-9090-7

Golden, L., \& Wiens-Tuers, B. (2006). To your happiness? Extra hours of labor supply and worker well-being. Journal of Socio-Economics, 35(2), 382-397. doi:10.1016/j.socec.2005.11.039

Gornick, J. C., \& Jacobs, J. A. (1998). Gender, the welfare state, and public employment: A comparative study of seven industrialized countries. American Sociological Review, 63(5), 688-710. doi:10.2307/2657334

Gregory, A., \& Milner, S. (2009). Editorial: Work-life balance: A matter of choice? Gender, Work and Organization, 16(1), 1-13. doi:10.1111/j.1468-0432.2008.00429.x

Haley-Lock, A. (2009). Variation in part-time job quality within the nonprofit human service sector. Nonprofit Management and Leadership, 19(4), 421-442. doi:10.1002/nml.v19:4

Handy, F., \& Katz, E. (1998). The wage differential between nonprofit institutions and corporations: Getting more by paying less? Journal of Comparative Economics, 26, 246-261. doi:10.1006/jcec.1998.1520

Hansmann, H. (1980). The role of nonprofit enterprise. Yale Law Journal, 89, 835-901. doi:10.2307/796089 [Crossref], [Web of Science ${ }^{\circledR}$ ], [Google Scholar]OpenURL University of Lincoln

Henly, J. R., Shaefer, H. L., \& Waxman, E. (2006). Nonstandard work schedules: Employer- and employee-driven flexibility in retail jobs. Social Service Review, 80(4), 609-634. doi:10.1086/508478

Hill, J. E., Grzywacz, J. G., Allen, S., Blanchard, V. L., Matz-Costa, C., Shulkin, S., \& Pitt-Catsouphes, M. (2008). Defining and conceptualizing workplace flexibility. Community, Work and Family, 11(2), 149-163. doi:10.1080/13668800802024678

Hurtado, D. A., Berkman, L. F., Buxton, O. M., \& Okechukwu, C. A. (2016). Schedule control and nursing home quality: Exploratory evidence of a psychosocial predictor of resident care. Journal of Applied Gerontology, 35(2), 244-253. doi:10.1177/0733464814546895

Kalleberg, A. L., \& Mastekaasa, A. (1998). Organizational size, layoffs, and quits in Norway. Social Forces, 76(4), 1243-1273. doi:10.1093/sf/76.4.1243

Kelly, E. L., \& Moen, P. (2007). Rethinking the clockwork of work: Why schedule control may pay off at work and at home. Advances in Developing Human Resources, 9(4), 487-506. doi:10.1177/1523422307305489

Kim, J., \& Wiggins, M. E. (2011, September/October). Family-friendly human resource policy: Is it still working in the public sector? Public Administration Review, 728-739. doi:10.1111/j.15406210.2011.02412.x

Kinnunen, U., \& Mauno, S. (1998). Antecedents and outcomes of work-family conflict among employed women and men in Finland. Human Relations, 51(2), 157-177. doi:10.1177/001872679805100203

Kryger, A. (2015). Casual employment in Australia: A quick guide (Parliamentary Library Research Paper Series). Canberra, Australia: Parliament of Australia, Department of Parliamentary Services. Retrieved from 
http://parlinfo.aph.gov.au/parllnfo/download/library/prspub/3612450/upload_binary/3612 450.pdf;fileType=application/pdf

Kugelberg, C. (2006). Constructing the deviant other: Mothering and fathering at the workplace. Gender, Work and Organization, 13(2), 152-173. doi:10.1111/gwao.2006.13.issue-2

Leete, L. (2001). Whither the nonprofit wage differential? Estimates from the 1990 Census. Journal of Labor Economics, 19(1), 136-170. doi:10.1086/209982

LeRoux, K., \& Feeney, M. K. (2013). factors attracting individuals to nonprofit management over public and private sector management. Nonprofit Management and Leadership, 24(1), 4362. doi:10.1002/nml.v24.1

Lewis, S., \& Humbert, A. L. (2010). Discourse or reality? "Work-life balance," flexible working policies and the gendered organization. Equality, Diversity and Inclusion: An International Journal, 29(3), 239-254. doi:10.1108/02610151011028840

Lindsay, J., \& Maher, J. (2014). The intersections of work time and care time: Nurses' and builders' family time economies. Work, Employment and Society, 28(2), 189-205. doi:10.1177/0950017013490331

Lindsay, J., Maher, J., \& Bardoel, A. (2009). Modified maternalism: Nurses and their families managing work and care in Australia. Journal of Comparative Family Studies, 40(4), 661-675.

Maher, J., Lindsay, J., \& Bardoel, E. A. (2010). Freeing time? The "family time economies" of nurses. Sociology, 44(2), 269-287. doi:10.1177/0038038509357205

Matz-Costa, C., \& Pitt-Catsouphes, M. (2009). Workplace flexibility as an organizational response to the aging of the workforce: A comparison of nonprofit and for-profit organizations. Journal of Social Service Research, 36(1), 68-80. doi:10.1080/01488370903333645

McCrate, E. (2012). Flexibility for whom? Control over work schedule variability in the US. Feminist Economics, 18(1), 39-72. doi:10.1080/13545701.2012.660179

McCurdy, A. H., Newman, M. A., \& Lovrich, N. P. (2002). Family-friendly workplace policy adoption in general and special purpose local governments: Learning from the Washington State experience. Review of Public Personnel Administration, 22(1), 27-51. doi:10.1177/0734371X0202200102

McDonald, C. (2006). Challenging social work: The institutional context of practice. Basingstoke, UK: Palgrave Macmillan.

McMenamin, T. M. (2007, December). A time to work: Recent trends in shift work and flexible schedules. Monthly Labor Review, 3-15. Retrieved from http://www.bls.gov/opub/mlr/2007/12/art1full.pdf

McNamara, T. K., Brown, M., \& Pitt-Catsouphes, M. (2012). Motivators for and barriers against workplace flexibility: Comparing nonprofit, for-profit, and public sector organizations. Community, Work and Family, 15(4), 487-500. doi:10.1080/13668803.2012.732789

Melbourne Institute of Applied Economic and Social Research. (2014). Household, income and labour dynamics in Australia (HILDA) Survey Annual Report 2013. Melbourne, Australia: University of Melbourne.

Mosca, M., Musella, M., \& Pastore, F. (2007). Relational goods, monitoring and non-pecuniary compensations in the non-profit sector: The case of the Italian social services. Annals of Public and Cooperative Economics, 78(1), 57-86. doi:10.1111/apce.2007.78.issue-1 
Nijp, H., Beckers, D., Geurts, S., Tucker, P., \& Kompier, M. (2012). Systematic review on the association between employee worktime control and work-non-work balance, health and well-being, and job-related outcomes. Scandinavian Journal of Work, Environment and Health, 38(4), 299-313. doi:10.5271/sjweh.3307

OECD. (2007). Babies and bosses-reconciling work and family life: A synthesis of findings for OECD countries. Paris, France: OECD.

Orloff, A. (2009). Gendering the comparative analysis of welfare states: An unfinished agenda. Sociological Theory, 27(3), 317-343. doi:10.1111/soth.2009.27.issue-3

Parry, E., Kelliher, C., Mills, T., \& Tyson, S. (2005). Comparing HRM in the voluntary and public sectors. Personnel Review, 34(5), 588-602. doi:10.1108/00483480510612530

Peters, P., Den Dulk, L., \& Van Der Lippe, T. (2009). The effects of time-spatial flexibility and new working conditions on employees' work-life balance: The Dutch case. Community, Work and Family, 12(3), 279-297. doi:10.1080/13668800902968907

Pocock, B. (2005). Work/care regimes: Institutions, culture and behaviour and the Australian case. Gender, Work and Organization, 12(1), 32-49. doi:10.1111/gwao.2005.12.issue-1

Pocock, B., Skinner, N., \& Ichii, R. (2009). Work, life and workplace flexibility: The Australian work and life index. Adelaide, Australia: Centre for Work and Life, Adelaide University.

Pocock, B., Skinner, N., \& Williams, P. (2012). Time bomb: Work, rest and play in Australia today. Sydney, Australia: New South.

Powell, A., \& Zhu, A. (2014, June 19-21). Trends in the availability and take-up of flexible work arrangements in Australia 2001-2010. Work and Family Researchers Network conference, New York, USA.

Richman, A. L., Civian, J. T., Shannon, L. L., Hill, J. E., \& Brennan, R. T. (2008). The relationship of perceived flexibility, supportive work-life policies, and use of formal flexible arrangements and occasional flexibility to employee engagement and expected retention. Community, Work and Family, 11(2), 183-197. doi:10.1080/13668800802050350

Rubery, J. (2013). Public sector adjustment and the threat to gender equality. In D. VaughnWhitehead (Ed.), Public sector shock: The impact of policy retrenchment in Europe (pp. 4384). Cheltenham, UK: Edward Elgar in association with the International Labour Organization.

Saltzstein, A. L., Ting, Y., \& Saltzstein, G. H. (2001). Work-family balance and job satisfaction: The impact of family-friendly policies on attitudes of federal government employees. Public Administration Review, 61(4), 452-467. doi:10.1111/puar.2001.61.issue-4

Sang, K. J. C., \& Powell, A. (2012). Equality, diversity, inclusion and work-life balance in construction. In A. Dainty \& M. Loosemore (Eds.), Human resource management in construction: Critical perspectives (pp. 163-196). Abingdon, UK: Routledge.

Shockley, K. M., \& Allen, T. D. (2012). Motives for flexible work arrangement use. Community, Work and Family, 15(2), 217-231. doi:10.1080/13668803.2011.609661

Skinner, N., \& Chapman, J. (2013). Work-life balance and family friendly policies. Evidence Base: A Journal of Evidence Reviews in Key Policy Areas, 2013(4), 1-25. Retrieved from https://journal.anzsog.edu.au/publications/10/EvidenceBase2013lssue4.

Stein, J. (2015). The impacts of worktime control in context: A comparison across occupations in the U.S. health care industry. Journal of Workplace Rights, 5(2), 1-17. 
Swanberg, J., Pitt-Catsouphes, M., \& Drescher-Burke, K. (2005). A question of justice: Disparities in employees' access to flexible schedule arrangements. Journal of Family Issues, 26(6), 866895. doi:10.1177/0192513X05277554

Sweet, S., Pitt-Catsouphes, M., Besen, E., \& Golden, L. (2014). Explaining organizational variation in flexible work arrangements: Why the pattern and scale of availability matter. Community, Work and Family, 17(2), 115-141. doi:10.1080/13668803.2014.887553

Ten Brummelhuis, L., \& Van Der Lippe, T. (2010). Effective work-life balance support for various household structures. Human Resource Management, 49(2), 173-193. doi:10.1002/hrm.v49:2

Underhill, E. (2005). Winners or losers? Work/life balance and temporary agency workers. Labour and Industry: A Journal of the Social and Economic Relations of Work, 16(2), 29-59. doi:10.1080/10301763.2005.10669322

Weisbrod, B. A. (1983). Nonprofit and proprietary sector behavior: Wage differentials among lawyers. Journal of Labor Economics, 1(3), 246-263. doi:10.1086/298012

Wilkins, R. (2015). The household, income and labour dynamics in Australia survey: Selected findings from waves 1 to 12. Melbourne, Australia: Melbourne Institute of Applied Economic and Social Research, University of Melbourne.

Williamson, S., Cooper, R., \& Baird, M. (2015). Job-sharing among teachers: Positive, negative (and unintended) consequences. Economic and Labour Relations Review, 26(3), 448-464. doi:10.1177/1035304615595740

\section{Funding}

This work was supported by an Australian Research Council Discovery Early Career Researcher Award (Project DE130100028). 